\title{
Investigation of Ethanol Stem Bark Extract of Treculia africana on the Haematological Parameters of Albino Wistar Rats
}

\author{
Nwankpa $\mathrm{P}^{1 *}$, Chukwuemeka $\mathrm{OG}^{2}$ and Ekweogu $\mathrm{CN}^{1}$ \\ ${ }^{1}$ Department of Medical Biochemistry, Imo State University, Owerri, Nigeria \\ ${ }^{2}$ Department of Biochemistry, Michael Okpara University of Agriculture, Umudike, Nigeria \\ *Corresponding author: Nwankpa P, Department of Medical Biochemistry, Imo State University, Owerri, Nigeria, Tel: 08039496554; E-mail: \\ promisenwankpa@yahoo.com
}

Received date: November 27, 2017; Accepted date: December 20, 2017; Published date: December 29, 2017

Copyright: (C) 2017 Nwankpa P, et al. This is an open-access article distributed under the terms of the Creative Commons Attribution License, which permits unrestricted use, distribution, and reproduction in any medium, provided the original author and source are credited.

\begin{abstract}
This study evaluated the effect of ethanol stem bark extract of Treculia africana (African bread fruit) on haematological status in wistar rats. Twenty four wistar rats were divided into four (4) groups. Group I received daily oral dose of $5 \mathrm{mg} / \mathrm{kg}$ of the extract, Group II received daily oral dose of $15 \mathrm{mg} / \mathrm{kg}$ of the extract, Group III received daily oral dose of $25 \mathrm{mg} / \mathrm{kg}$ of the extract while Group IV received normal saline and served as the control. After 21 days of treatment, the rats were sacrificed and plasma obtained for haematological assay. Result showed that there was a significant $(P<0.05)$ increase in packed cell volume $(\%)$ in test groups $(39.66 \pm 0.57 ; 37.65 \pm 0.47 ; 38.74 \pm$ $0.38)$ and Hemoglobin level $(\mathrm{g} / \mathrm{dl})(17.86 \pm 0.23 ; 17.1 \pm 0.15 ; 17.43 \pm 0.28)$ compared to the control $(34.33 \pm 0.57)$ and $(14.70 \pm 0.15)$ respectively. Red blood cell count (cell/litre) revealed an insignificant $(P>0.05)$ increase in test groups compared to control. There were significant $(\mathrm{P}<0.05)$ increases in mean corpuscular volume $(\mathrm{MCV})$ and mean corpuscular hemoglobin $(\mathrm{MCH})$ in group III (110.53 \pm 0.15 and $50.83 \pm 0.80)$ compared to control $(100.76 \pm$ 1.67 and $45.76 \pm 0.82)$ respectively. Furthermore, the white blood cells (WBC) showed significant $(P<0.05)$ increase in test groups $(6.93 \pm 0.50,9.50 \pm 0.57,9.13 \pm 0.42)$ compared to the control $(5.23 \pm 0.52)$. Lymphocytes $(\%)$ revealed a significant $(P<0.05)$ decrease in group $1(36.56 \pm 3.60)$ compared to control $(4.66 \pm 0.57)$ while neutrophils $(\%)$ showed a significant $(P<0.05)$ increase in test groups $(62.23 \pm 2.51,64.36 \pm 3.78,59.66 \pm 4.50)$ compared to the control $(50.20 \pm 6.08)$. The results of this study revealed that the extract is capable of stimulating red blood cell formation (erythropoiesis) and an active phagocytic agent against foreign compounds and may be useful for haemopoietic conditions.
\end{abstract}

Keywords: Treculia africana; Haematological parameters; Wistar rats; Erythropoiesis; Stem bark

\section{Introduction}

Herbal medicine have received greater attention as alternative to clinical therapy in recent times leading to subsequent increase in their demand [1,2]. In rural communities, the exclusive use of herbal drugs, prepared and dispensed by herbalist without formal training, for the treatment of disease is still very common. Scientific investigation is therefore required for evaluation of the claimed activity and to ascertain the safety and efficiency of these herbal products as well as to establish their active constituent [3]. Research work on some medicinal herbs have shown that they have definite action on nervous, circulatory, respiratory, digestive and renal systems; as well as sexual organs, the skin, vision, hearing and taste [4].

Treculia africana belongs to the family of Moraceae. It is an evergreen forest tree which is about $10-30 \mathrm{~m}$ in height and $3 \mathrm{~m}$ in girth with a dense spreading crown and fluted trunk. Commonly called African bread fruit, it is a plant food native to tropical West and parts of East Africa. The seeds are extracted after macerating the fruit in water and ground to meal, known as bread fruit flour which can be used to produce a variety of baked food. Ethnomedically, it is used as a verbrifuge, versmifuge galactogogue and laxative [3]. According to Irvine [5], the roots of Treculia africana are used as malaria tonic, worm expeller, neck swelling and rheumatism. The pods and seeds of
Treculia africana has been shown to contain flavonoids, polyphenols, polysaccharides cardiac glycosides, saponins and anthraquinones which are known to have antimicrobial activity [6,7]. The presence of these secondary metabolites accounts for its use for medicinal purposes [8]. The seed of Treculia africana has been shown to contain beta-carotene, vitamin $\mathrm{C}$, folic acid [9], magnesium, potassium and calcium [10]. The bark decotion is used for the treatment of cough, leprosy and seed meal is added to soap [11]. Anaemia is a medical ailment or disease in which the red blood cell count or haemoglobin is less than normal. Normal range of haemoglobin varies in males and females. The normal haemoglobin level for men is $13.5 \mathrm{~g} / 100 \mathrm{ml}$ while in women it is $12.0 \mathrm{~g} / 100 \mathrm{ml}$ [12]. Haemoglobin levels less than the normal is medically called anaemia. Haemolytic anaemia is known to be produced by excessive destruction or shortened erythrocyte lifespan [13]. In chemically induced anaemia, the primary alteration is a marked reduction in the number of leukocytes and erythrocytes [14].

Blood constituents change in relation to the physiological status of an animal and thus act as a pathological reflector of the status of the animals [15]. There are many blood disorders which can affect the quality as well as the functionality of blood cells or proteins in the blood clothing system or immune system [16]. In Nigeria, stem bark of Treculia africana is used traditionally to cure many ailments but reports are scanty on the effect on the haematological parameters. Hence this study is aimed at investigating the effect of ethanol stem bark extract of Treculia africana on haemotological parameters in wistar rats. 
Citation: Nwankpa P, Chukwuemeka OG, Ekweogu CN (2017) Investigation of Ethanol Stem Bark Extract of Treculia africana on the Haematological Parameters of Albino Wistar Rats. Biochem Anal Biochem 6: 347. doi:10.4172/2161-1009.1000347

Page 2 of 4

\section{Materials and Methods}

\section{Plant material}

The stem bark of Treculia africana was harvested from its original habitat at a farmland in Obazu Mbieri in Mbaitoli LGA of Imo State. It was authenticated by Dr. F. Mbagwu of the Department of Plant Science and Biotechnology, Imo State University, Owerri. The bark was chopped to pieces, washed and cleaned under running tap water and dried at room temperature for four weeks. The dried bark was ground to a fine powder with mechanical grinder and kept in air-tight container, under dry condition until required for use.

\section{Preparation of ethanol stem bark extract of Treculia africana}

Modified method [17] was adopted for the extraction. Three hundred $(300 \mathrm{~g})$ of grounded stem bark of Treculia africana was macerated in $150 \mathrm{ml}$ absolute ethanol for 48 hours after which it was filtered with sterile filter paper (Watman No. 1). With the aid of a rotary evaporator the filtrate was evaporated to dryness at $40^{\circ} \mathrm{C}$ after which it was stored at $5^{\circ} \mathrm{C}$ in a refrigerator until required for use.

\section{Animals}

Animal model used for this study were albino wistar rats weighing between 140-170 g. The rats were acclimatized to daily handling in the animal house of Imo State University, Owerri for 7 days and maintained ad-libitum on water and normal rat chow (product of Pfizer Nig. Ltd).

\section{Experimental design}

Twenty-four rats used in this study were divided into 4 groups of 6 rats each. The groups were labeled and orally administered with stem bark extract of Treculia africana as shown below:

- Group I received $1 \mathrm{mI} 5 \mathrm{mg} / \mathrm{kg}$ body weight of stem bark extract of Treculia africana.

- Group II received $1 \mathrm{mI} 15 \mathrm{mg} / \mathrm{kg}$ body weight of stem bark extract of Treculia africana.

- Group III received $1 \mathrm{ml} 25 \mathrm{mg} / \mathrm{kg}$ body weight of stem bark extract of Treculia africana.
- Group IV received $1 \mathrm{ml}$ normal saline (control).

The treatment period lasted for twenty-one (21) days during which the animal had access to feed and water ad-libitum.

\section{Blood sample collection}

After 48 hours of the treatment, the rats were sacrificed under chloroform anaesthesia and dissected to expose cardiac cavity. Blood sample from each rat was collected by cardiac puncture using a sterile syringe $(5 \mathrm{ml})$ and carefully dispensed into ethylene diamine tetraacetic acid (EDTA) bottle as to prevent clotting. The sample bottles were carefully labeled accordingly for all the four groups.

\section{Haemotological analysis}

The methods [12,18] were used to assay the haematological parameters. These include packed cell volume (PCV), Haemoglobin concentration $(\mathrm{Hb})$, red blood cell count (RBC count), white blood cell count (WBC count), platelet count (PLT count), differential WBC, (neutrophil, lymphocyte, eosinophil) and red cell indices [mean corpuscular volume $(\mathrm{MCV})$, mean corpuscular haemoglobin $(\mathrm{MCH})$ and mean cell haemoglobin concentration (MCHC)]. All the haematological parameters were estimated using the sysmex (c) Automated Haematology Analyzer KX-21 N, Sysmex Corporation, Kobe Japan.

\section{Statistical analysis}

The experimental data were expressed as mean \pm SEM and analyzed for statistical significance by one-way analysis of variance using SPSS window statistical software programme. This was followed by student's t-test of significance. The mean difference at $\mathrm{P}<0.05$ were considered statistically significant.

\section{Results}

The results of the haematological assay on the effect of ethanol stem bark extract of Treculia africana in wistar rats are presented in Tables I and 2 .

\begin{tabular}{|c|c|c|c|c|c|c|c|}
\hline Group & Treatment & PCV (\%) & $\mathrm{Hb}(\mathrm{g} / \mathrm{dl})$ & RBC (x106 ml-1) & $\operatorname{MCV}(p g)$ & $\mathrm{MCH}(\mathrm{pg})$ & $\mathrm{MCHC}(\mathrm{g} / \mathrm{dl})$ \\
\hline I & $\begin{array}{l}5 \mathrm{mg} / \mathrm{kg} \text { stem bark } \\
\text { extract of TA }\end{array}$ & $39.66 \pm 0.57^{*}$ & $17.86 \pm 0.23^{*}$ & $4.20 \pm 0.10^{*}$ & $98.66 \pm 0.60$ & $43.56 \pm 0.57$ & $45.06 \pm 0.05$ \\
\hline II & $\begin{array}{l}15 \mathrm{mg} / \mathrm{kg} \text { stem bark } \\
\text { extract of TA }\end{array}$ & $37.65 \pm 0.47^{\star}$ & $17.10 \pm 0.15^{\star}$ & $3.60 \pm 0.30$ & $103.26 \pm 0.40$ & $47.13 \pm 0.63$ & $46.16 \pm 0.15$ \\
\hline III & $\begin{array}{l}25 \mathrm{mg} / \mathrm{kg} \text { stem bark } \\
\text { extract of TA }\end{array}$ & $38.74 \pm 0.38^{*}$ & $17.43 \pm 0.28^{*}$ & $3.50 \pm 0.25$ & $110.53 \pm 1.50^{*}$ & $50.83 \pm 0.80^{*}$ & $46.98 \pm 0.26$ \\
\hline IV & $\begin{array}{l}\text { Normal saline } \\
\text { (control) }\end{array}$ & $34.33 \pm 0.57$ & $14.70 \pm 0.15$ & $2.50 \pm 0.70$ & $100.76 \pm 0.82$ & $45.76 \pm 0.82$ & $44.23 \pm 0.75$ \\
\hline
\end{tabular}

Data are presented as Mean \pm SEM of three determinants $n=6, \mathrm{PCV}$ : Packed Cell Volume; Hb: Haemoglobin; MCH: Mean Corpuscular Haemoglobin; MCHC: Mean Corpuscular Haemoglobin Concentration; RBC: Red Blood Cell, *Significant at $\mathrm{P}<0.05$, TA: Treculia africana.

Table 1: Effect of ethanol stem bark extract of Treculia africana on red blood cell, packed cell volume, haemoglobin and red cell indices in wistar rats.

The result showed a significant $(\mathrm{P}<5,0.05)$ increase in a dose dependent manner in PCV and hemoglobin when compared to the control. Also RBC in group I, MCV in group Ill and $\mathrm{MCH}$ in group Ill showed significant $(\mathrm{P}<0.05)$ increases when compared to the control as 
Page 3 of 4

shown in Table 1. However, there was insignificant $(\mathrm{P}>0.05)$ increases in $\mathrm{MCHC}$ of the treated groups when compared to the control shown as in Table 1 . The WBC count and neutrophil indicated a significant $(\mathrm{P}<0.05)$ increase in groups I, II and III when compared to the control while platelets indicated significant $(\mathrm{P}<0.05)$ increase only in group II and Ill when compared to the control as shown in Table 2. However, the result of this study showed a significant $(\mathrm{P}<0.05)$ decrease only in lymphocytes in group I when compared to the control.

\begin{tabular}{|l|l|l|l|l|l|l|}
\hline Group & Treatment & Platelet $\mathbf{x} 103 \mathrm{~mL}^{-1}$ & WBC $\mathbf{x 1 0 3} \mathrm{mL}^{-1}$ & Lymphocyte (\%) & Neutrophil (\%) & Eosinophil (\%) \\
\hline I & $\begin{array}{l}5 \mathrm{mg} / \mathrm{kg} \text { stem bark } \\
\text { extract of TA }\end{array}$ & $775.68 \pm 2.42$ & $6.93 \pm 0.50^{*}$ & $36.56 \pm 3.60^{*}$ & $62.33 \pm 2.51^{*}$ & $3.33 \pm 0.11$ \\
\hline II & $\begin{array}{l}15 \mathrm{mg} / \mathrm{kg} \mathrm{stem} \mathrm{bark} \\
\text { extract of TA }\end{array}$ & $780.46 \pm 2.67^{*}$ & $9.50 \pm 0.57^{*}$ & $45.10 \pm 1.00$ & $64.36 \pm 3.78^{*}$ & $2.36 \pm 0.82$ \\
\hline III & $\begin{array}{l}25 \mathrm{mg} / \mathrm{kg} \mathrm{stem} \mathrm{bark} \\
\text { extract of TA }\end{array}$ & $782.75 \pm 3.46^{*}$ & $9.13 \pm 0.42^{*}$ & $47.33 \pm 2.08$ & $59.6 \pm 4.50^{*}$ & $3.01 \pm 0.20$ \\
\hline IV & $\begin{array}{l}\text { Normal } \\
\text { saline(control) }\end{array}$ & $768.71 \pm 3.21$ & $5.23 \pm 0.52$ & $47.66 \pm 0.57$ & $50.20 \pm 6.08$ & $2.66 \pm 0.15$ \\
\hline
\end{tabular}

Data are presented as Mean \pm SEM of three determinations; $n=6$, WBC: White Blood Cell. *Significant at $P<0.05$, TA: Treculia africana.

Table 2: Effect of ethanol stem bark extract of Treculia africana on platelets, white blood cells and differential cell count in wistar rats.

\section{Discussion}

The assessment of haematological parameters are useful guide to ascertaining the effect of foreign substances including plant extracts on a given organism. They are used to determine possible alterations in the levels of biomolecules such as enzymes, metabolic products, haematology, normal functioning and histopathology of the organs $[19,20]$. The present study showed significant increases in PCV and Hb concentrations in test groups as compared to control. While the result of this study on PCV is in agreement with the report [21], the result of $\mathrm{Hb}$ concentration which showed a marginal decrease on administration of root bark extract of Treculia africana on diabetic rats is in contrast with the result of this study. Also, the result of this study reveal significant increases in red blood cell count in test group I, MCV and $\mathrm{MCH}$ in test group III while in test group II, RBC, MCV and $\mathrm{MCH}$ showed marginal increases compared to the control. Similar results were obtained by Esenowo et al. and Okon et al. [22,23]. This haematopoietic condition may have resulted from different mechanisms including increase in rate of blood cell synthesis and or decrease in rate of blood cells destruction. Either of the two mechanisms may have been responsible for the increase in the red cell indices. The plant extract may have the potential to stimulate erythropoietin release in the kidney which increases the synthesis of red cells [24] and or help fight against infections and microbial invasions [23] which destroys blood cells both of which may culminate to increases in blood cells seen in this study. The mean value of total WBC count, platelets and neutrophils of test groups were significantly $(\mathrm{P}<0.05)$ increased when compared to the control. This result supports the observation made [25] who suggested that increase in red blood cells stimulate cytokine erythropoietin. Treculia africana extract may possibly stimulate cytokine erythropoietin to stimulate blood cell synthesis. Furthermore, WBC and neutrophil increase suggest the ability of stem bark extract of Treculia africana to boost the cells immune system since they function as active phagocytic agents against foreign compounds [26]. This may possibly explain its use in management of anaemia and related ailments.

\section{Conclusion}

This study investigated the effects of ethanol stem back extract of Treculia africana on haematological parameters in wistar rats. The result demonstrated that the extract is capable of stimulating blood cell formation and act as active phagocytic agent against foreign compounds. It therefore supports its use as nutraceutical for haemopoietic conditions.

\section{References}

1. Sushruta K, Satyanarayana S, Srinivas N, Sekhar RJ (2006) Evaluation of the blood-glucose reducing effects of aqueous extracts of the selected Umbellifereous fruits used in culinary practice. Tropical Journal of Pharmaceutical Research 5: 613-617.

2. Ogbonnia SO, Mbaka GO, Adekunle A, Anyika EO, Gbolade OE, et al. (2010) Effect of poly-herbal formulation, Okudiabet on Alloxan-induced diabetic rats. Agriculture and biology Journal of North America 1: 139-145.

3. Ogbonnia SC, Odimegwu JI, Enwuru VN (2008) Evaluation of hypoglycemic effect of aqueous Ethanol Extract of Treculia africana Decne and Bryophyllum pinnatum Lam. and their mixture on streptozotocin (STZ)-induced diabetic rats. African Journal of Biotechnology 7: 2535-2539.

4. Bailey CJ, Day C (1989) Traditional plants medicines as treatments for diabetes. Diabetes Care 12: 52-556.

5. Irvine JI (1981) Comparative Study of the Chemical Composition and Mineral Element Content of Treculia africana Seeds and Seed Oils. Journal of Food Engineering 40: 241-244.

6. Chukwu A, Ofoeflule SI, Ugoeze K (1994) Studies on the pharmaceutical application of a polysaccharide derived from (Treculia africana) fruit. Bulletin de Ia Societe de France 36: 539-544.

7. Akubor PI, Badilb GO (2004) Chemical composition, functional properties and baking potential of African breadfruit kernel and wheat flour blends. International Journal of Food Science and Technology 39: 223-229.

8. Okafor JC (1985) Selection and Improvement of Indigenous Tropical Fruit Trees: Problems and Prospects. Journal of Forestry Research 1: 87-95.

9. Ugwoke FN (2003) Nutritional Composition of Treculia africana seed. Dissertation, University of Nigeria. Nsukka. 
Citation: Nwankpa P, Chukwuemeka OG, Ekweogu CN (2017) Investigation of Ethanol Stem Bark Extract of Treculia africana on the Haematological Parameters of Albino Wistar Rats. Biochem Anal Biochem 6: 347. doi:10.4172/2161-1009.1000347

Page 4 of 4

10. Okafor JC (1990) Indigenous Trees of the Nigerian Rainforest. A Paper Presented in a symposium on the Potentials for Domestication and Rebuilding of Forest resources. Yaounde, Cameroon 34-38.

11. Mbuya LP (1994) Useful Trees and Shrubs for Tanzania: Identification, Propagation and Management for Agricultural and Pastural Communities. Regional Soil Conservation Unit (RSCU), Swedish International Development Authority (SIDA), pp: 160-164.

12. Lewis SN, Bain BJ, Bates I (2001) Dacie and Lewis: practical haematology, (9thedn), Elsevier London, pp: 9-40.

13. Shutt OA, MacDonald IW (1965) Rate of hemoglobin synthesis after blood loss in sheep and influence of dietary protein. Australian Journal of Experimental Biology and Medical Science 43: 475-488.

14. Adejumo DO (2005) Performance, organ development and haematology of rats fed sole diets of graded levels of cassava flour and soyabean (soygari) as substitutes for energy and protein concentrates. Tropical Journal of Animal Science 7: 57-63.

15. Nse-Abasi NE, Williams ME, Akpabio U, Offiong EA (2014) Haematological Parameters and factors affecting their Values. Agricultural Science 2: 37-47.

16. Kuter DJ (2012) Overview of Blood Disorders In Merck Manual of Haematology. Harvard Medical School: Massachusetts General Hospital, pp: $82-85$.

17. Abdulrahman F, Inyang SI, Abdah J, Buda L, Amos S (2004) Effect of aqueous lead extract of Irvingia fabonesis on gastrointestinal tract of rodents. Indian J Exp Biol 42: 787-791.

18. Choudhari CV, Deshmukh PB (2007) Acute and subchronic toxicity of semecarpus anacardium on haemoglobin percent and RBC count of male albino rats. Journal of Herbal Medicine and Toxicology 1: 43-45.

19. Magalhaes P, Appell H, Duarte J (2008) Involvement of advanced glycation and products in the pathogenesis of diabetes complication, the protective role of regular physical activity. European Review of Aging and Physical Activity 5: 17-29.

20. Oyedemi SC, Adewusi EA, Aiyegoro CA, Akinpelu DA (2011) Antidiabetic and Haematological Effect of Aqueous Extract of Stem bark of Afzelia Africana (Smith) on streptozotocin-induced Diabetic Wistar Rats. Asian Pacific Journal of Tropical Biomedicine 1: 353-358.

21. Ogbonnia SO, Anyika EN, Mbaka GO, Utah P, Ugwu D, et al. (2012) Antihyperglycaemic and antiheperlipidaemic effects of aqueous Ethanol extract of Tapinanthus globiferus leaves and Treculia africana root bark and their mixture on alloxan diabetic rats. Agriculture and Biology Journal of North America 3: 237-246.

22. Esenowo GJ, Sam SM, Bala DN, Ekpo BA, Edung EM (2010) Phytochemical screening and the haematological effect of Peristrophe bicalycuta (RETZ) Nees diet preparation in albino rats. World Journal of Applied Science and Technology 2: 277-281.

23. Okon JE, Esenowo GJ, Afaha IP, Umoh NS (2013) Hematopoietic parameters of ethanolic fruits extract of musa accumulate on albino rats. Bull. Env. Pharmacol. Life Sci 2: 22-26.

24. Mbaka GO, Adeyemi OO, Oremosu AA (2010) Acute and sub-chronic toxicity studies of the ethanol extract of the leaves of Sphenocentrum jollyanum (menispermaceae). Agriculture and Biology Journal of North America 1: 265-272.

25. Ahumibe AA, Braide VB (2009) Effect of gavage treatment with pulverized Garcinakola seeds on Erythrocyte membrane integrity and selected haematological indices in male albino wistar rats. $\mathrm{Ng} \mathrm{J}$ Physiological Sci 24: 47-52.

26. Teguia A, Telefo PB, Fosto RG (2007) Growth performances, organ development and blood parameters of rats fed raded levels of steeped and cooked taro tuber (Esculenta) meal. Livestock Research for Rural development 19: 1-8. 